\title{
AiMT
}

Advances in Military Technology

Vol. 12, No. 1 (2016), pp. 5-20

ISSN 1802-2308, eISSN 2533-4123

DOI 10.3849/aimt.01135

\section{Developments in the Classification of Aviation Accidents in Czechoslovak and Czech Military Aviation}

\author{
O. Zavila* \\ Department of Fire Protection, VSB - Technical University of Ostrava, Czech Republic
}

The manuscript was received on 27 July 2016 and was accepted after revision for publication on 27 January 2017.

\begin{abstract}
:
The article deals with the classification of emergency occurrences in Czechoslovak and Czech military aviation from 1946 to mid-2016. It lists available information sources and presents original definitions laid down therein, as well as many logical links and indications leading to the formulation of development trends in this field. The knowledge and proper understanding of the classification scales for emergency occurrences in both the Czechoslovak and the Czech military aviation in different periods is the key to understanding and correct interpretation of the statistics of aviation accidents and their preconditions. Statistics, the systematic mathematical processing of professional experience, is one of important bases for a positive development in any sector, which is also the case in military aviation.
\end{abstract}

\section{Keywords:}

Army of the Czech Republic, Czechoslovak Army, Czechoslovak People's Army, aviation accident, aviation occurrence, aviation emergency occurrence, development trend

\section{Introduction}

In order to develop, every field of human activity requires a certain amount of selfreflection that helps to determine future orientations and optimize work processes. In military aviation, as in many other fields, one way of self-reflecting is to keep and continuously evaluate statistics of aviation accidents or other emergency occurrences.

Roots of numerous successes, problems or even failures can often be found in either recent or more distant past. It is necessary to be able to read, understand and

\footnotetext{
* Corresponding author: Department of Fire Protection, VSB - Technical University of Ostrava, Lumírova 13/630, CZ-700 30 Ostrava, Czech Republic.

Phone: +420 597322 893, E-mail: ondrej.zavila@vsb.cz
} 
interpret statistical data which even now may be valuable and relevant, although they were recorded and classified according to rules that no longer apply.

A good example may be the statistics of aviation accidents that even today, if interpreted in proper historical, technical and legislative contexts, can not only give evidence of basic principles of the inception and development of aviation safety, but also provide the best arguments for observing the presently well-known safety rules. To understand and interpret the aviation accidents statistics correctly, it is crucial to become familiar with the contents and basic definitions provided in aviation regulations and with logical links and development trends according to which the aviation accidents and other emergency occurrences were classified at the time.

\section{Aviation Regulations for Classification of Aviation Accidents, Aviation Occurrences and Aviation Emergency Occurrences}

From 1946 to mid-2016, thirteen regulations were issued successively for the use of the Czechoslovak and later Czech Air Force to classify "aviation accidents" (hereinafter “AA”),"aviation occurrences” (hereinafter “AO”), “aviation emergency occurrences” (hereinafter “AEO”), "preconditions for aviation accidents” (hereinafter "PAA") and other types of emergency occurrences.

The first regulation was the Aviation Accidents [1] directive issued in 1946. It was followed by the Let-I-5 (or Let-1-5) regulation, first issued in 1950 [2] and amended in 1953 [3], 1955 [4], 1960 [5], 1962 [6], 1968 [7], 1972 [8], 1974 [9], 1979 [10], 1991 [11] and 2000 [12]. The last (2000) Let-1-5 regulation edition was replaced by the Všeob-P-10 Flight Safety [13] regulation in 2006.

Terms and their definitions set out in aviation directives and regulations for the classification of aviation emergency occurrences applied in different periods are given in the following overview (see sections 2.1 to 2.13 below). The frequent verbatim citing is not without purpose, but rather necessary for subsequent analysis. Also, it provides resource information for potential future researchers who might approach the trend and logical links analysis in a different way than the author, or for a different purpose.

Most of the documents were obtained in the Administrative Archives of the Armed Forces of the Czech Republic in Olomouc [14], a smaller part in the Military Central Archives in Prague [15].

\subsection{Aviation Accidents (1946 Directive)}

According to the degree/ extent of the damage to the aircraft, aviation accidents were classified into groups I - IV:

I. Repair of the aircraft could be performed on the spot.

II. Repair of the aircraft had to be carried out in repair workshops.

III. The aircraft had to be sent to factory for repair.

IV. The aircraft was completely destroyed.

The second classification concerned the crew's health state:
A. The crew sustained no or slight injuries.
B. The crew was seriously injured or killed.
C. The multi-member crew was killed.

Combinations of Roman numerals and letters described the aviation accident (e.g. IA, IIC). Such division applied to all aviation accidents, whether at the airfield, in emergency landing, in flight or when operating the aircraft on the ground. The di- 
rective did not contain any further information related to the classification and definition of aviation accidents [1].

\subsection{Let-I-5 Aviation Accidents (1950 Aviation Regulation)}

This was the first in a series of eleven editions of regulations designated Let-I-5 issued in an amended form until 2000.

"Aviation accident" (hereinafter "AA") was defined as any damage to the aircraft or injury to the aircraft crew that took place between the engine start and the engine shutdown after flight. There were five types of AAs: disaster, air crash, damage, emergency (forced) landing and accidents caused by loss of orientation.

"Disaster" was an aviation accident associated with the death or severe injury to the crew or some of its members regardless of the degree of damage to the aircraft.

"Air crash" was a total or partial destruction of the aircraft with no deaths or with only minor injuries of the crew. The aircraft could not be repaired by the means of the air base.

"Damage" was a partial destruction of the aircraft that could be repaired by the means of the air base regardless of the injuries to the crew.

"Forced landing" was an early landing of the crew outside the airfield or in an unassigned airfield spot.

"Loss of orientation" was a situation when the crew lost general orientation and landed without knowing the position of the aircraft on the ground.

The degree of seriousness of an aviation accident was always determined by the most severe outcomes [2].

\subsection{Let-I-5 Aviation Occurrences and Procedure for their Investigation (1953 Avia- tion Regulation)}

"Aviation occurrence" (hereinafter "AO”) was defined as damage to or destruction of the aircraft, its parts, fuselage, engine, weapons or special equipment, death or injury to the crew or persons on board in flight. There were four types of AOs: disaster, air crash, damage and forced landing.

"Disaster" was an aviation occurrence in which the crew or some of the passengers were killed regardless of the degree of damage to the aircraft.

"Air crash" was the damage to the aircraft or engine that could not be repaired or required an overhaul in the factory or in stable repair shops taking minimum of 1500 hours of work and replacement of major parts or assemblies.

"Damage" was partial damage to the aircraft or engine that could be repaired in the field conditions by means of a "Field Aviation Repair Shop 1" and "Field Aviation Repair Shop 4" and the extent of work required less than 500 hours of work and only a partial replacement of components.

"Field Aviation Repair Shops 1" were mobile repair military trucks with a crew of two to three persons who were able to carry out minor repairs of aviation technology at the Air Regiment level. "Field Aviation Repair Shops 4" were stable aviation repair shops that provided extensive repairs of aviation technology at the Air Division level. The system of Field Aviation Repair Shops 1 to 4 operated for MiG-15s, MiG17s, MiG-19s, MiG-21s and Su-7s. There was no such a follow-up system for more complex aircraft of later generations.

Forced landing was an early termination of a flight with airfield or off-airfield landing and no damage to the aircraft. If the aircraft was damaged, the occurrence was 
classified as a disaster, air crash or damage. Early termination of a flight due to adverse weather conditions was not classified as forced landing unless the aircraft was damaged [3].

\subsection{Let-I-5 Classification, Investigation and Prevention of Aviation Occurrences (1955 Aviation Regulation)}

“Aviation occurrence” (hereinafter “AO”) was defined as an occurrence associated with the flight task fulfillment that took place after the pilot started the engine at the aircraft stand in preparing for flight until he switched off the engine at the aircraft stand after the flight. Again, there were four types of AOs: disaster, air crash, damage and forced landing.

"Disaster" was an AO which resulted in death of crew members or passengers at the time of destruction of or damage to the aircraft. The same classification applied when an injury resulted in death within five days of the occurrence, or the aircraft crew did not return, or it was not found in subsequent search operations.

"Air crash" was a destruction of the aircraft unassociated with the death of crew members or passengers or with damage to the aircraft requiring an overhaul. The same classification applied to aircraft loss in a forced landing when displacement of the aircraft was impossible but it was possible to rescue the crew members (e.g. landing on water, in a swamp or in the woods).

"Damage" was an AO in which the damage to the aircraft did not require an overhaul. Damage to the aircraft was classified as minor damage and not considered an $\mathrm{AO}$ if repair did not require replacement of drive components and could be performed by the unit personnel within 25 hours of work for single-engine, 50 hours of work for twin-engine and 100 hours of work for four- and multiengine aircraft.

"Forced landing" was an unforeseen successful airfield or off-airfield landing of the aircraft due to a complete or partial failure of aviation technology, early consumption of fuel, loss of orientation or ill health of the crew during the flight. An unforeseen landing was not classified as a forced landing, if it was ordered from the ground or decided by the group commander for the flight and successfully executed on one's own or other airfield. If the aircraft was damaged or there were other severe consequences in the forced landing, the situation was classified by the degree of the actual AO.

Death or injury to crew members or passengers without damage to the aircraft or destruction of and damage to the aircraft technology the causes of which were unrelated to flight and thus they were regarded as "emergency occurrences” [4].

\subsection{Let-1-5 Classification and Method of Investigation of Aviation Emergency Oc- currences (1960 Aviation Regulation)}

“Aviation emergency occurrence” (hereinafter “AEO”) was defined as an occurrence associated with the fulfillment of a flight task that happened in the period after the pilot started taxiing from the aircraft (helicopter) stand until he stopped taxiing at the aircraft (helicopter) stand after landing. There were three types of AEOs: disasters, air crashes and damage.

"Disaster" was an AEO which resulted in death of crew members or passengers and destruction of or damage to the aircraft or in serious injuries resulting in death within the next ten days. The same classification applied when the crew did not return and the aircraft was not found in subsequent search operations. 
"Air crash" was a total destruction of the aircraft or serious injury to the crew members (passengers), but not their death or damage to the aircraft to such an extent that repair would not be practical. The same classification applied to emergency landings where the displacement of the aircraft from the landing site was not possible or practical but the crew and passengers were rescued regardless of the damage to the aircraft (landing on water or in a muddy or otherwise difficult terrain).

"Damage" was an AEO in which the aircraft was so damaged that it required repair.

Damage to the aircraft was classified as "minor damage” and not considered an AEO if repair did not require replacement of bear loading components and could be performed by the personnel within 25 hours of work for light aircraft, 50 hours of work for single-engine, 100 hours of work for twin-engine and 200 hours of work for four-engine aircraft. Also, a discontinuation of a flight was not classified as AEO, if it was caused by a complete or partial failure of the aircraft technology or by other circumstances preventing the flight task fulfillment.

Death of crew members and passengers during the flight and landing was classified under "other emergency occurrences" and not considered an AEO if there was no damage to the aircraft. The same classification applied if persons not fulfilling the flight task died on ground when the aircraft fell or was damaged [5].

\subsection{Let-1-5 Classification and Investigation of Aviation Emergency Occurrences (1962 Aviation Regulation)}

“Aviation emergency occurrence” (hereinafter “AEO”) was defined as a situation caused by the aircraft crew, the aircraft itself or defects in air traffic organization and security. It was manifested by an emergency that occurred after the crew started the engine with the intention of flight until the aircraft stopped moving and the engine stopped running. There were four types of AEOs: disaster, air crash, damage and aviation emergency occurrences with favourable ending.

"Disaster" was an AEO in which the crew or passengers died or suffered serious injuries leading to death. The same classification applied when the crew did not return and was not found.

"Air crash" was an AEO in which the aircraft was totally destroyed or the crew members (passengers) were seriously injured or the aircraft was so damaged that repair would not be practical. The same classification applied to emergency landings where the displacement of the aircraft from the landing site was not possible or practical but the crew and passengers were rescued regardless of the extent of damage to the aircraft (landing on water or in a muddy or otherwise difficult terrain).

"Damage" was an AEO in which the aircraft was so damaged that it required repair.

“Aviation emergency occurrence with favourable ending” was an AEO in which the emergency was successfully resolved by the crew and the air traffic control authorities. This classification also applies to aircraft damage the repair of which did not require replacement of bear loading components and could be performed by the unit personnel in less than 25 hours of work for light aircraft, 50 hours of work for singleengine, 100 hours of work for twin-engine and 200 hours of work for four-engine aircraft.

Events when, in an emergency, persons died on ground when the aircraft fell or was damaged were not regarded as AEOs but as "other emergency occurrences" [6]. 


\subsection{Let-1-5 Classification and Investigation of Aviation Accidents (1968 Aviation Regulation)}

"Aviation accident” (hereinafter "AA") was defined as an occurrence in which an emergency occurred after the crew started the engine with the intention of flight until the engine stopped running and the aircraft stopped moving. There were four types of AAs: disaster, air crash, damage and minor accident.

"Disaster" was an AA in which the crew or the passengers were killed or fatally injured. The same classification applied when the crew did not return and was not found.

"Air crash" was an AA in which the aircraft was totally destroyed or the crew members or passengers suffered serious injuries or the aircraft was so damaged that repair would not be practical. The same classification applied to emergency landings where the displacement of the aircraft from the landing site was not possible or practical, but the crew and passengers were rescued regardless of the extent of damage to the aircraft (landing on water or in a muddy or otherwise difficult terrain).

"Damage" was an AA in which the aircraft was damaged in a manner corresponding to at least one of the following options:

a) The change of the aircraft geometry exceeded the permitted tolerances.

b) The aircraft was so damaged that it could not be repaired with the resources of the respective army unit.

c) The engine was damaged to such an extent that it had to be replaced before the revision period expired.

"Minor damage" was an AA which:

a) resulted in damage to the aircraft that did not qualify for "damage" as defined above.

b) gave reason for a discontinuation of a flight for safety reasons.

c) remained without consequences although an emergency had occurred.

Injury or death of persons situated outside the aircraft during the aviation accident was not classified as AA but as an "emergency occurrence" [7].

\subsection{Let-1-5 Classification, Investigation, Record-keeping and Prevention of Avia- tion Accidents and Their Preconditions (1972 Aviation Regulation)}

"Precondition for Aviation Accident" (hereinafter "PAA") was defined as any disruption, deficiency or defect in organization and security of a flight mission (flight), in the flight mission (flight), as well as during the flight control that created the possibility of an emergency in flight.

“Grave PAAs” were particularly dangerous PAAs, important in terms of prevention.

"Aviation accident” (hereinafter "AA") was defined as substantial damage to or destruction of the aircraft airframe or engine, injury or death of the crew (passengers) that took place after the engine was started with the intention of flight until the aircraft and the engine stopped moving after landing or until the wreckage stopped moving, including extinguishing the fire and rescuing or finding the crew (passengers). There were three types of AAs: disaster, air crash and damage.

"Disaster" was an AA in which the crew members or passengers were killed or fatally injured.

"Air crash" was an AA in which the aircraft was totally destroyed or irreversibly lost (landing on water or in an inaccessible or swampy terrain), or the crew and pas- 
sengers suffered serious injuries, or the aircraft was so damaged that repair would not be practical.

"Damage" was an AA in which the aircraft was damaged in a manner corresponding to at least one of the following options:

a) The change of the aircraft geometry exceeded the permitted tolerances.

b) The aircraft airframe was so damaged that it required replacement of carrying (control) surfaces or it could not be repaired with the resources of the respective army unit.

c) The engine was damaged to such an extent that it had to be replaced before the revision period expired.

Damage to the aircraft smaller than that listed in the definition of "damage" (see above) was classified as PAA [8].

\subsection{Let-1-5 Classification, Investigation, Record-keeping and Prevention of Avia- tion Accidents and Their Preconditions (1974 Aviation Regulation)}

"Precondition for Aviation Accident" (hereinafter "PAA) was defined as an event that reduced the flight safety forcing the flight crew or the flight control authorities to perform activities which were usually beyond the scope of the flight task in order to complete the flight successfully. Flight was defined as the movement of the aircraft from the start of the take-off run until the end of the landing roll (for vertical takeoff and landing from the engine power increase for lift-off until the engine power reduction after touchdown).

“Aviation Accident” (hereinafter "AA”) was defined as damage to or destruction of the aircraft when in flight mission was performed by the pilot (flight crew) after leaving the aircraft stand for taking off until entering the aircraft stand after landing. There were three types of AAs: disaster, air crash and damage.

"Disaster" was an AA in which the flight crew members or passengers were killed or seriously injured in connection with the damage or destruction of the aircraft.

"Air crash" was an AA in which the aircraft was totally destroyed with non-fatal consequences for the flight crew or passengers or it was so damaged that repair would not be practical. The same classification applied to the loss of aircraft due to emergency landing at a location from which the aircraft recovery and displacement would be impossible or impracticable (landing on water, in a swampy or difficult terrain) when the flight crew members and passengers were rescued.

"Damage" was an AA which resulted in such damage to the aircraft that it had to be handed over for repair outside the military unit.

Death of flight crew members (passenger) during take-off, in flight or landing without any connection with the damage or destruction of the aircraft and injury or death of persons situated outside the aircraft during the AA (or PAA) was classified as “emergency occurrence” [9].

\subsection{Let-1-5 Classification, Investigation, Record-keeping and Prevention of Aviation Accidents and Their Preconditions (1979 Aviation Regulation)}

This regulation [10] could not be found in any military institutions, archives, museums or private collections in either the Czech Republic or the Slovak Republic.

Its content and classification can be at least approximately deduced from historical sources issued before and after this regulation and based on the information from witnesses. Its existence is confirmed by references provided in subsequent Let-1-5 
regulation of 1991 (see below) and especially by the fact that it served as a source material for two out of five military textbooks written by Col. Stanislav Slavík, a flight safety senior inspector in the $10^{\text {th }}$ Air Force in Hradec Králové from 1960s to 1980s that were dealing with statistical analyses of air accidents between 1981 and 1984 [1620]. The textbooks were nicknamed "Nightingale Songs" (Slavičí zpěvy in Czech) for the author's last name (Slavík in Czech means Nightingale in English).

The classification of AAs probably remained the same as in previous 1974 Let-15 regulation standard, but the classification of PAAs was extended by "serious PAAs" and "very serious PAAs”. Unfortunately, further details are currently unknown.

\subsection{Let-1-5 Flight Safety (1991 Aviation Regulation)}

"Precondition for Aviation Accident" (hereinafter "PAA) was defined as an event which endangered the flight safety by creating a dangerous flight situation that, in order to complete the flight successfully, had to be resolved by the crew or the flight control authorities by performing an activity which was beyond the scope of the flight task or air traffic control procedures and possibly claimed performing emergency tasks, procedures and an early termination of the flight.

Flight was defined as the movement of the aircraft from the start of the take-off run until the end of the landing roll (for vertical takeoff and landing, from the engine power increase for lift-off until the engine power reduction after touchdown).

“Aviation accident” (hereinafter "AA") was defined as an occurrence in flight in which:

a) The crew members (passengers) were killed or seriously injured due to direct contact with any part of the aircraft or by the action of jet blast (produced by the aircraft) except when the death or injury was from natural causes, selfinflicted or inflicted by other persons.

b) The aircraft was destroyed, damaged or there was a malfunction that required major repair or replacement of damaged parts.

There were three types of AAs: disaster, air crash and damage.

"Disaster" was an AA in which lives were lost among the crew (passengers).

"Air crash" was an AA in which the aircraft was totally destroyed or irreversibly lost with non-fatal consequences for the flight crew (passengers) or it was so damaged that repair would not be possible or practical.

"Damage" was an AA which resulted in such damage to the aircraft that it had to be handed over for repair outside the military unit.

Malfunctions and damage limited to the engine and damage limited to the rotor blades, propellers, wing rims, antennas, tires, brakes and aerodynamic covers were not considered as AAs.

Death or injury to the crew (passengers) in flight without any connection with the damage or destruction of the aircraft and injury or death of persons who were not on board was not classified as AA but as "emergency occurrence".

Other classified occurrences were: defect and malfunction, deficiency, error, negligence and recklessness.

"Defect and malfunction" were events involving erroneous activity of persons or faulty operation of aircraft and its equipment or means for flight security, the manifestations of which did not affect flight safety to qualify for classification as PAA. 
"Deficiency" was any erroneous activity of command authorities, crews, technical and supporting personnel and traffic control organization during the preparation, execution and securing of flying.

"Error" was an incorrect activity in causal connection with the emergence or progress of a dangerous flight situation. It resulted from psychological and physiological boundaries of human performance.

"Negligence" was inflicting of causes and circumstances of a dangerous flight situation where the offender committed a violation of applicable regulations or proceeded erroneously due to ignorance, although they should and could have the necessary knowledge considering their qualification or position.

"Recklessness" was inflicting of causes and circumstances of a dangerous flight situation where the offender believed without adequate reasons that violation of regulations or procedures would not have any negative consequence although they were aware of it [11].

\subsection{Let-1-5 Flight Safety (2000 Aviation Regulation)}

"Precondition for Aviation Accident" (hereinafter "PAA) was defined as such an evaluation of the consequences of a dangerous situation in air traffic when the flight crew or air traffic control authorities were forced to perform activities that were beyond the scope of the flight task, current flight plan or air traffic control procedures or the situation required to perform non-standard (emergency) procedures or early termination of the flight. The consequences of the dangerous situation consisted in:

- A minor injury of any person on board (except when ill health was from natural causes, self-inflicted or inflicted by other persons).

- Damage to the aircraft that did not affect the main part of the aircraft structure and it was possible and practical to repair it by the military unit itself.

- Malfunctioning of special equipment for maintaining the ability of the flight crew and passengers to work or if any of the crew members experienced health problems.

- Risk of damage to the aircraft or health threat to the crew and passengers.

In the original of the regulation, this initial definition is followed by a sixteenparagraph list of typical situations. The list only specifies the definition in concrete situations; therefore, given the scope of the article, it is not quoted here.

Flight was defined as the movement of the aircraft from the start of the take-off run until the end of the landing roll (attaining zero velocity or velocity prescribed for taxiing). For vertical takeoff and landing it was from the moment when the landing gear lifted off from the surface until it touched the surface when landing.

Taxiing was defined as the movement of the aircraft under its own power from the engine start until the beginning of the take-off run (vertical takeoff) and from the end of the landing roll until the engine switch-off at the aircraft stand.

Air traffic was a collective term for the operation of all aircraft in flight, when taxiing and with running engines at aircraft stands.

"Aviation accident" (hereinafter "AA") was defined as the designation for the consequences of the degree of an air traffic occurrence in which:

a) the crew members or passengers were killed or seriously injured except when the death or injury was from natural causes, self-inflicted or inflicted by other persons. 
b) the aircraft was destroyed, damaged or there was a malfunction that required major repair or replacement of main airframe parts.

There were three types of AAs: disaster, air crash and damage.

"Disaster" was an AA in which lives were lost among the crew (passengers).

"Air crash" was an AA in which the aircraft was totally destroyed or irreversibly lost with non-fatal consequences for the flight crew and passengers or so damaged that repair would not be possible or practical.

"Damage" was an AA in which the flight crew members or passengers were not fatally or seriously injured, but the aircraft was so damaged that the aircraft or the main airframe part had to be handed over for repair outside the military unit or a repair team called to the military unit specifically for this purpose had to carry out the repair.

Damage was not:

- malfunction of or damage to the engines or their accessories or covers.

- damage limited to propellers, helicopter rotor blades, edges and peripheral parts of wings, antennas, antenna covers, tires, brakes, fairings, cockpit canopies, ailerons, flaps, break shields and slots.

Death or serious injury to the crew (passengers) without any connection with the damage or destruction of the aircraft and serious injury or death of persons who were not on board was not classified as AA but as "emergency occurrence".

Other classified occurrences were: defect and malfunction and ground accident.

"Defect and malfunction" were such evaluations of the consequences of a dangerous situation where erroneous activity of the crew or other persons, disruption in operability or faulty operation of aircraft and ground facilities in flight traffic, its control and securing affected flight safety only to a small extent and were not subject to reporting as PAAs.

"Ground accident" was an occurrence that took place in other situations of the aircraft than those defined as air traffic, in connection with the preparation of the aircraft for flight, with its manipulation, upkeeping or parking, and resulted in ill health or death of a person or in damage to or destruction of the aircraft [12].

\subsection{Všeob-P-10 Flight Safety (2006 Aviation Regulation)}

This regulation is a moderately revised variant of the previous one. A few minor changes were made in definitions and the classification of "preconditions for aviation accident” (hereinafter "PAA") was slightly extended by "serious PAAs".

The definition of an aviation accident (hereinafter "AA") was supplemented by events in which the aircraft is missing or completely inaccessible.

It is worth mentioning, among other things, that for aviation accidents prevention purposes, dangerous situations are currently also considered PAAs if they came to an end accidentally without being responded to by the flight crew or the air traffic control unit or were averted by an avoiding action or were found afterwards.

Serious PAAs are dangerous situations arising between military and civil aircraft or when air traffic controllers of military air traffic services are involved in creating a dangerous situation for civil aircraft or serious occurrences in which the risk of an AA was imminent.

The definitions of disasters, air crashes and damage did not change [13]. 


\section{Development Trends and Other Interesting Facts}

Although it might seem that working with regulations can hardly give a picture of historical reality and developments in the field, it does not have to be necessarily so. From the information given above and having examined the full texts of the military aviation regulations, which the excerpts come from, we can state the following facts.

The regulations for classification of AAs and other air emergency occurrences can be viewed in terms of stylistic means and factual content. These aspects have had its evolution reflecting both historical and current technological developments in military aviation and political situation in the country.

As for the stylistics, the development trend has moved from full sentences to sentences supplemented and interspersed by bulleted, lettered or numbered lists.

As for the factual content, the development trend has moved from brief definitions in single-clause sentences through more complex definitions in longer multiclause sentences to exhaustive definitions in long multi-clause sentences supplemented by the bulleted, lettered or numbered lists of examples of typical situations.

Brief definitions in short sentences were given in the first three regulations of 1946, 1950 and 1953. More complex definitions in longer sentences were gradually emerging in the following regulations of 1955, 1960 and 1962. Since 1968, the regulations have commonly contained information or criteria in bulleted, lettered or numbered lists. The most complex explanations with examples of typical situations have been given in recent regulations, i.e. those of 2000 and 2006.

Another aspect that affected the factual content of the regulations is the purpose for which the statistics were kept. It can be deduced from the contents of the definitions and the entire classification system. The overview table shown below (see Fig.1) can be very helpful in this matter.

\begin{tabular}{|c|c|c|c|c|c|c|c|c|c|c|c|c|c|c|c|c|c|c|c|c|c|c|c|c|c|c|c|c|c|}
\hline \multirow[t]{2}{*}{ Regulation or directive } & \multirow[t]{2}{*}{ Year } & \multicolumn{28}{|c|}{ Classification } \\
\hline & & 1. & 2. & 3. & 4. & 5. & 6. & 7. & 8. & 9. & 10. & 11. & 12. & 13. & 14. & 15. & 16. & 17. & 18. & 19. & 20. & 21. & 22. & 23. & 24. & 25. & 26. & 27. & 28. \\
\hline Aviation Accident directive & 1946 & $\bullet$ & $\bullet$ & $\bullet$ & $\bullet$ & $\bullet$ & $\bullet$ & $\bullet$ & & & & & & & & & & & & & & & & & & & & & \\
\hline \begin{tabular}{|l|} 
Let-1-5 regulation \\
\end{tabular} & 1950 & & & & & & & & $\bullet$ & $\bullet$ & - & & - & $\bullet$ & & & & & & & & & & & & & & & \\
\hline \begin{tabular}{|l|} 
Let-1-5 regulation \\
\end{tabular} & 1953 & & & & & & & & $\bullet$ & $\bullet$ & $\bullet$ & & • & & & & & & & & & & & & & & & & \\
\hline Let-1-5 regulation & 1955 & & & & & & & & $\bullet$ & $\bullet$ & $\bullet$ & $\bullet$ & $\bullet$ & & & & & & & & & & & & & & & $\bullet$ & \\
\hline Let-1-5 regulation & 1960 & & & & & & & & $\bullet$ & $\bullet$ & $\bullet$ & $\bullet$ & & & & & & & & & & & & & & & & & $\bullet$ \\
\hline \begin{tabular}{|l|} 
Let-1-5 regulation \\
\end{tabular} & 1962 & & & & & & & & - & $\bullet$ & •• & & & & & • & & & & & & & & & & & & & - \\
\hline \begin{tabular}{|l|} 
Let-1-5 regulation \\
\end{tabular} & 1968 & & & & & & & & $\bullet$ & $\bullet$ & $\bullet$ & & & & $\bullet$ & & & & & & & & & & & & & - & \\
\hline Let-1-5 regulation & 1972 & & & & & & & & $\bullet$ & $\bullet$ & $\bullet$ & & & & & & - & $\bullet$ & & & & & & & & & & & \\
\hline \begin{tabular}{|l|} 
Let-1-5 regulation \\
\end{tabular} & 1974 & & & & & & & & $\bullet$ & $\bullet$ & $\bullet$ & & & & & & $\bullet$ & & & & & & & & & & & - & \\
\hline Let-1-5 regulation & 1979 & & & & & & & & • & $\bullet$ & $\bullet$ & & & & & & - & & • & - & & & & & & & & & \\
\hline \begin{tabular}{|l|} 
Let-1-5 regulation \\
\end{tabular} & 1991 & & & & & & & & $\bullet$ & $\bullet$ & $\bullet$ & & & & & & $\bullet$ & & & & $\bullet$ & $\bullet$ & $\bullet$ & $\bullet$ & $\bullet$ & & & - & \\
\hline Let-1-5 regulation & 2000 & & & & & & & & $\bullet$ & $\bullet$ & $\bullet$ & & & & & & $\bullet$ & & & & & & & & & $\bullet$ & $\bullet$ & & \\
\hline Všeob-P-10 regulation & 2006 & & & & & & & & $\bullet$ & $\bullet$ & $\bullet$ & & & & & & - & & $\bullet$ & & & & & & & $\bullet$ & $\bullet$ & & \\
\hline
\end{tabular}

Fig.1 Development of emergency occurrences classification in Czechoslovak and

Czech Military Aviation in 1946-2016: (1.-4.) I.-IV. Classification by degree of dam-

age to aircraft, (5., 6., 7.) A, B, C Classification by crew's state of health,

(8.) Disaster, (9.) Air crash, (10.)Damage, (11.) Minor damage, (12.) Forced landing, (13.) Loss of orientation, (14.) Minor accident, (15.) Aviation emergency occurrence with favourable ending, (16.) Precondition for aviation accident, (17.) Precondition

for aviation accident - grave, (18.) Precondition for aviation accident - serious,

(19.) Precondition for aviation accident - very serious, (20.) Defect and malfunction in air traffic, (21.) Ground accident, (22.) Deficiency, (23.) Error, (24.) Negligence, (25.) Recklessness, (26.) Defect and malfunction, (27.) Emergency occurrence, (28.) Other emergency occurrence 
The table clearly shows, among other things, that the purpose of keeping statistics in military aviation was changing over time. From the AA classification system from the post-war era a deduction can be made that damage and losses were recorded for the purpose of economic evaluation of the state of the staff and equipment more than for anything else. This trend was still applied until the early 1960s. However, in the Let-1-5 regulation of 1962, the "Aviation emergency occurrence with favourable ending”, a predecessor of later PAAs, appeared for the first time. At this point, the statistics of AAs ceased to be a mere basis for the economic evaluation of the state of the staff and equipment and they began to provide also valuable information for developments in aviation accidents prevention. It was possible to draw on experiences that did not come out fatally and to build upon lessons learned. The motivation was clear to improve Czechoslovak Air Force's quality and capacity for action and thereby enhance the defence capability of the country. It was not surprising in the light of the international political situation and statistics of AAs in the 1950s. In 1950-1960 there were 91 disasters and 60 air crashes with a total of 103 deaths of pilots just for military jet aircraft [21-25].

As for quality, the classification system and statistics keeping have improved. The history shows that with a decreasing number of military aircraft and with their increasing combat value, the classification system and statistics keeping has become more complex and detailed. Although the country's economic interests have always been and most likely will be at the forefront, with time the statistics provide more and more sources for prevention of emergency occurrences.

The development in this field has also brought significant changes that often make comparison of statistical data sets from different periods impossible. What are the common characteristics and differences in the development of classifications and definitions of AAs or other monitored emergency occurrences?

The common and always monitored characteristics that can be relied upon in all historical periods include: the death of persons, destruction of aircraft and aircraft reparability in relation to the extent of damage. Since 1960s, a tendency to lessonlearning can also be joined to the list.

The differences include changes in terminology and definitions, not by a continuous expansion of their content foundations, but often by a radical change of the root characteristics. That is why harmonization of statistical data from different periods is so complicated today. This can be evidenced by the development of the definitions for all types of AAs and PAAs.

Over the past seventy years, the very concept of an AA has been changed three times: first to AO (in 1953-1960), then to AEO (in 1960-1968) and finally back to AA (since 1968). The number of AA types was decreasing from 12 in 1946 to 5 in 1950 and 4 in 1953, 1955, 1962 and 1968 (except in 1960 when there were only 3 types of AAs) to be finally reduced to 3 types of AAs in 1972 (until present). The definition of the AA time-frame also changed practically in every new regulation. The AA time-frame was formulated as follows:

A. No specification (1946 regulation).

B. After the engine start until the engine switch-off after flight (1950 and 1955 regulations).

C. In flight - no definition of "flight" (1953 regulation).

D. After the start of taxiing before flight until the stop of taxiing after landing (1960 regulation). 
E. After the engine start before flight until the engine stopped running and the aircraft stopped moving after flight (1962 and 1968 regulations).

F. After the engine start before flight until the aircraft and the engine stopped moving after flight or until the wreckage stopped moving, fire was extinguished or the crew or passengers were found or rescued (1972 regulation).

G. After leaving the aircraft stand for taking off until entering the aircraft stand after landing (1974 regulation).

H. In flight - from the start of the take-off run until the end of the landing roll (1991 regulation).

I. In air traffic - in flight, when taxiing and with running engines (2000 and 2006 regulations).

Definitions of disasters, air crashes and damage as types of AAs were officially entered into the Let-I-5 regulation in 1950 and they also have considerably changed. The 1946 directive can of course be seen as a predecessor of this classification where, from the perspective of today's definitions, up to eight types of AAs could be regarded as a disaster (IB-IVB and IC-IVC), two as an air crash (IVA and possibly IIIA) and two as damage (IIA and possibly IA).

Definitions of these terms were most notably changing from the early 1950s to early 1960s. Serious efforts were evident to clearly specify the extent of occurrences, not only by means of worded but also numbered expressions. For example, a criterion was specified for disasters that took into account the death of the crew or passengers as a result of injuries sustained during an AA up to 5 days (in 1955) or even 10 days (in 1960) after the AA occurred. For air crashes, the components and degree of irreparable damage to the aircraft were particularized. The definition of damage as a type of an AA was changing throughout the period most notably and for the longest time (until the early 1990s). Therefore, it is very difficult to find common denominators for "damage" in different historical periods.

From 1960s to 1980s, the form of most definitions stabilized with the exception of "damage". The early 1990s have seen last appreciable changes in formulations and most definitions of AAs have been stable and valid ever since.

An interesting concept in the classification of aviation emergency occurrences is the PAA. Although it was first defined in the 1972 Let-1-5 regulation, its predecessor can be identified as early as in 1962 as "aviation emergency occurrences with favourable ending” (see section 2.6) or in 1968 as "minor accidents" (see section 2.7). Both of these concepts by parts of their definitions complied with the preventative educational function of later PAAs. It could be argued that even "forced landing”, "loss of orientation" and "minor damage" classified in 1950, 1953, 1955 and 1960 (see sections 2.2 to 2.5) would fall within today's definition of PAAs. However, their definitions did not comply with the PAA's preventative educational function. In the late 1970s efforts were evident to specify the wide range of the PAA classification by introducing the concepts of "serious PAAs" and "very serious PAAs" but these efforts were not further developed in 1991 and 2000 regulations. Partial extension of the PAA classification, again by serious PAAs, was not realized until the last Všeob-P-10 regulation in 2006. In the last two regulations (in 2000 and more notably in 2006), the intention is obvious to give the most comprehensive definition of PAAs, also due to the fact that this classification has had the largest share in the statistics for the past 30 years. This is also caused by the fact that the definition for damage changed and a considerable portion of occurrences previously classified as damage fell under PAAs. 
Another, and certainly not the last, interesting fact is that helicopters, or vertical take-off aircraft, were not included into AA classification regulations in the Czechoslovak military aviation until 1960 (see section 2.5).

\section{Conclusion}

Prominent changes have been noted in regulations for the classification of aviation emergency occurrences over the past 70 years. The statistics of AAs, PAAs and other monitored emergency occurrences compiled and kept pursuant hereto have generated a great deal of knowledge and experience for the positive development of military aviation. The general perspective, however, shows at least two interesting facts that have not brought any positive thing and could be a subject for reflection.

The first fact is perhaps too excessive and too frequent variability of definitions and classification scales. It is partly understandable especially in the 1950s when the Czechoslovak military aviation was replacing propeller fighters for jet fighters. The change in the propulsion principle and to some extent also in aircraft control gave rise to completely new and unknown problems resulting in emergency situations never experienced before. Later, however, the experience evolved, and yet various experimental classifications were introduced and root definitions of basic terms were modified. Instead of systematic extension and clarification of the basic generic classification, changes were made that make it largely impossible now to unify the findings from different historical periods and the present. Only cases with fatal consequences for aircraft or their crews can be reliably tracked in all historical periods but much more interesting facts that could help in lesson learning can be found particularly in emergency occurrences that did not end fatally as testimony of participants and aviation technology involved is available.

The second fact is the poor utilization and appreciation of the information value of "positive experiences". All directives and regulations for the classification of AAs, PAAs and other emergency situations issued so far have been focused solely on recording, classification and subsequent utilization of "negative experiences". Positive experiences in coping with aviation emergencies are not included although they may have the same or even higher information value for the development in aviation accidents prevention. As unbelievable as it may seem, this idea was formulated 35 years ago by Col. Stanislav Slavík in his $3^{\text {rd }}$ book of staff manuals [18] and it is still valid. Higher appreciation and deeper analyses of "positive experience" could contribute in the future to the development in aviation accidents prevention, as well as to increasing motivation and morale of the flight and non-flight staff. This problem has already been addressed in the current Air Force of the Czech Republic.

In contrast to the facts mentioned above, what can be found very positive is the move towards maximum accuracy, systematization, objectification of the AA and PAA classification in regulations in recent years, and especially the maximum effort to learn lessons from all mistakes and setbacks which can help current and future generations of pilots.

This article has been drawn up as a systematic review of available thematically focused military aviation regulations presented in annotated contexts that can provide guidance for both aviation professionals and non-experts in the statistics of AAs, PAAs and other emergency occurrences between 1946 and 2016.

Despite the small criticism above, the author would like to express his sincere gratitude and appreciation to all who participated or participate in the development of 
regulations for the classification of AAs, PAAs and other emergency occurrences in the military aviation of the former Czechoslovakia and the Czech Republic. Their effort and honest work contribute significantly to improving the level of quality and safety of flying in military aviation which, among other things, increases the level of safety and protection of the country.

\section{Acknowledgment}

The author would like to thank Lt. Col. Miroslav Němec, Lt. Col. Karel Valvoda, Col. Petr Chamrad, Mr. Miroslav Irra, Mr. Libor Režňák, Lt. Col. (Ret.) František Pisch, Mr. Miroslav Mihalík, Mr. Miroslav Hájek and Col. (Ret.) Josef Pavlík for good will, valuable advice, observations and comments on this work.

\section{References}

[1] Aviation Accidents [directive, K no. 12.416/let. - 1946] (in Czech). $1^{\text {st }}$ ed. Prague: Ministry of National Defence, 1946 [Military Central Archives in Prague].

[2] Aviation Accident [regulation Let-I-5] (in Czech). $1^{\text {st }}$ ed. Prague: Ministry of National Defence, 1950 [Military Central Archives in Prague].

[3] Aviation Occurrences and Procedure for Their Investigation [regulation Let-I-5] (in Czech). $1^{\text {st }}$ ed. Prague: Ministry of National Defence, 1953 [Administrative Archives of the Armed Forces of the Czech Republic in Olomouc].

[4] Classification, Investigation and Prevention of Aviation [regulation Let-I-5] (in Czech). $1^{\text {st }}$ ed. Prague: Ministry of National Defence, 1955 [Administrative Archives of the Armed Forces of the Czech Republic in Olomouc].

[5] Classification and Method of Investigation of Aviation Emergency Occurrences [regulation Let-1-5] (in Czech). $1^{\text {st }}$ ed. Prague: Ministry of National Defence, 1960. NV-0031413/60 [Administrative Archives of the Armed Forces of the Czech Republic in Olomouc].

[6] Classification and Investigation of Aviation Emergency Occurrences [regulation Let-1-5] (in Czech). $1^{\text {st }}$ ed. Prague: Ministry of National Defence, 1962. T PVOSL-261-62 [Administrative Archives of the Armed Forces of the Czech Republic in Olomouc].

[7] Classification and Investigation of Aviation Accidents [regulation Let-1-5] (in Czech). $1^{\text {st }}$ ed. Prague: Ministry of National Defence, 1968. T MNO-40-62-68 [Administrative Archives of the Armed Forces of the Czech Republic in Olomouc].

[8] Classification, Investigation, Record-keeping and Prevention of Aviation Accidents and Their Preconditions [regulation Let-1-5] (in Czech). $1^{\text {st }}$ ed. Prague: Ministry of National Defence, 1972. T MNO-40-176-71 [Administrative Archives of the Armed Forces of the Czech Republic in Olomouc].

[9] Classification, Investigation, Record-keeping and Prevention of Aviation Accidents and Their Preconditions [regulation Let-1-5] (in Czech). $1^{\text {st }}$ ed. Prague: Ministry of National Defence, 1974. T MNO-40-175-74 [Administrative Archives of the Armed Forces of the Czech Republic in Olomouc]. 
[10] Classification, Investigation, Record-keeping and Prevention of Aviation Accidents and Their Preconditions [regulation Let-1-5] (in Czech). $1^{\text {st }}$ ed. Prague: Ministry of National Defence, 1979.

[11] Flight Safety [regulation Let-1-5] (in Czech). $1^{\text {st }}$ ed. Stará Boleslav: Federal Ministry of Defence, 1991 [Administrative Archives of the Armed Forces of the Czech Republic in Olomouc].

[12] Flight Safety [regulation Let-1-5] (in Czech). $1^{\text {st }}$ ed. Prague: Ministry of Defence, 2000 [Administrative Archives of the Armed Forces of the Czech Republic in Olomouc].

[13] Flight Safety [regulation Všeob-P-10] (in Czech). $1^{\text {st }}$ ed. Prague: Ministry of Defence, 2006.

[14] Military Central Archives: Administrative Archives of the Armed Forces of the Czech Republic. Military Central Archives: Administrative Archives of the Armed Forces of the Czech Republic [online]. Prague, 2010 [cited 2016-05-10]. Available from: <http://www.vuapraha.cz/archiv-ACR>.

[15] Military Central Archives: Homepage. Military Central Archives: Homepage [online]. Prague, 2010 [cited 2016-05-10]. Available from: $<$ http://www.vuapraha.cz>.

[16] SLAVÍK, S. Overview of Aviation Accidents, Serious Preconditions and Preventive Experience (Book 1) (in Czech). $1^{\text {st }}$ ed. Hradec Králové, 1979.

[17] SLAVÍK, S. Overview of Aviation Accidents, Serious Preconditions and Preventive Experience (Book 2) (in Czech). $1^{\text {st }}$ ed. Hradec Králové, 1979.

[18] SLAVÍK, S. Overview of Aviation Accidents, Serious Preconditions and Preventive Experience (Book 3) (in Czech). $1^{\text {st }}$ ed. Hradec Králové, 1981.

[19] SLAVÍK, S. Overview of Aviation Accidents, Preconditions and Preventive Experience 1981-1982 (in Czech). $1^{\text {st }}$ ed. Hradec Králové, 1986.

[20] SLAVÍK, S. Overview of Aviation Accidents, Preconditions, Deficiencies and Preventive Experience 1983-84 (in Czech) $1^{\text {st }}$ ed. Hradec Králové, 1989.

[21] IRRA, M. Aero Avia S/CS-92 (in Czech). $1^{\text {st }}$ ed. Nevojice: Jakab Publishing, 2014. ISBN 978-80-87350-17-1.

[22] IRRA, M. MiG-15: Vol. 3. (Bi-lingual English/Czech publication). $1^{\text {st }}$ ed. Nevojice: Jakab Publishing, 2007, 96 p., ISBN 978-80-87161-01-2.

[23] IRRA, M. MiG-17: The “Seventeen" (Bi-lingual English / Czech publication). $1^{\text {st }}$ ed. Nevojice: Jakab Publishing, 2012, 128 p., ISBN 978-80-87350-10-2.

[24] IRRA, M. Ilyushin Il-28: The Ilyushin Il-28 in the Czechoslovak Air Force (Bilingual English/Czech publication). $1^{\text {st }}$ ed. Nevojice: Jakab Publishing, 2013, 128 p., ISBN 978-80-87350-12-6.

[25] IRRA, M. The Mikoyan-Gurevich MiG-19 in Czechoslovak Air Force (in Czech). $1^{\text {st }}$ ed. Nevojice: Jakab Publishing, 2014, 128 p., ISBN 978-80-87350-15-7. 